7-1-2014

\title{
Exploring Gender and Self-Efficacy Ratings of Athletic Training Students over Time
}

\author{
W. David Carr \\ Missouri State University \\ Jennifer Volberding
}

Follow this and additional works at: https://bearworks.missouristate.edu/articles-chhs

\section{Recommended Citation}

Carr, W. David, and Jennifer L. Volberding. "Exploring gender and self-efficacy ratings of athletic training students over time." Athletic Training Education Journal 9, no. 3 (2014): 127-134.

This article or document was made available through BearWorks, the institutional repository of Missouri State University. The work contained in it may be protected by copyright and require permission of the copyright holder for reuse or redistribution.

For more information, please contact BearWorks@library.missouristate.edu. 


\title{
Exploring Gender and Self-Efficacy Ratings of Athletic Training Students over Time
}

\author{
W. David Carr, PhD, ATC*; Jennifer L. Volberding, PhD, ATC $\dagger$
}

*The University of Kansas, Lawrence; †Oklahoma State University, Stillwater. Dr Carr is currently at Missouri State University, Springfield.

Objective: To describe the development of a self-efficacy instrument and to explore the changes by gender in student selfefficacy ratings over 1 year.

Design and Setting: An exploratory study utilizing an instrument that measures self-efficacy in undergraduate students in a university setting.

Patients or Other Participants: Thirty students (13 males and 17 females) enrolled in the professional phase of an undergraduate athletic training program.

Main Outcome Measure(s): Student ratings of self-efficacy were measured using the Self-Efficacy in Athletic Training Student instrument. Validity was established through a panel of experts. Cronbach $\alpha$ was used to establish the reliability of the instrument. The instrument was administered 3 times during an academic year. Students were asked to rate their level of self-efficacy on a Likert scale $(1=$ not at all confident; $5=$ very confident) on 16 components within 3 content areas. Descriptive statistics were calculated, and a nonparametric analysis of variance was used to determine differences in selfefficacy based upon time for each gender. Post hoc contrasts were used to examine when significant differences occurred among the 3 measures.

Results: The internal consistency for the overall instrument and each content area ranged from $\alpha=0.91$ to 0.96 . Analysis of variance indicated statistically significant differences $(P<.003)$ across the 3 times, with significant changes in self-efficacy by gender, with greater increases for females across the 3 measures to similar male levels of self-efficacy at the final measure.

Conclusions: Students' self-efficacy can be affected by many factors, some of which may be controlled or influenced. We have developed reliable measure for assessing student self-efficacy. It is the desire of the authors that athletic training programs will develop strategies to improve the efficacy of their students and use this method to assess the effectiveness of those strategies.

Key Words: Self-confidence, self-esteem, self-assessment, athletic training education

Please address all correspondence to W. David Carr, PhD, ATC, Missouri State University, 901 S. National, Springfield, MO 65897. wdavidcarr@missouristate.edu.

Full Citation:

Carr WD, Volberding JL. Exploring gender and self-efficacy ratings of athletic training students over time. Athl Train Educ J. 2014;9(3):127-134. 


\title{
Exploring Gender and Self-Efficacy Ratings of Athletic Training Students over Time
}

\author{
W. David Carr, PhD, ATC; Jennifer L. Volberding, PhD, ATC
}

\section{INTRODUCTION}

Self-efficacy can be defined as a person's belief about his/her ability to successfully perform a given behavior. Albert Bandura ${ }^{1}$ put forth a ground-breaking self-efficacy model as part of his social cognitive theory. In this model, self-efficacy is derived from 4 sources: (1) past accomplishments, (2) vicarious experiences, (3) verbal persuasion, and (4) emotional arousal. Past accomplishments are experiences in which the person mastered the designated task, while vicarious experiences are experiences in which someone observes a peer or mentor completing the task. An example of a previous accomplishment involves an individual producing a customized foot orthotic versus a vicarious experience of watching someone else produce the orthotic. Verbal persuasion requires social support from a credible source, and emotional arousal is an intrinsic reaction to the environment and task. According to this model, a student with high levels of efficacy will perform better than a student with low levels of efficacy, which leads to increasing levels of self-efficacy, giving way to higher performance. ${ }^{2}$ Studies ${ }^{3,4}$ have documented that students' increased efficacy may be a result of their education experiences.

Measures of self-efficacy need to be specific to a given task to increase the accuracy of predicted outcomes based upon a belief. $^{2}$ All too often, self-efficacy measures are global and lack specificity. Generalized self-efficacy instruments assess people's general confidence and abilities without specifying the tasks or situations. ${ }^{5}$ Self-efficacy research has focused on 2 main areas: (1) the relationship between efficacy and college major/career choices 6,7 and (2) the relationship between efficacy and motivation/achievement. ${ }^{5,8-11}$ The first area of research provides insight into career development and gender differences. The second has supported that self-efficacy is correlated to various psychological constructs, such as selfregulation, ${ }^{1}$ rewarding contingencies, ${ }^{10}$ and anxiety and selfconcept. ${ }^{5}$ However, the manner in which self-efficacy has been measured varies widely, and direct comparisons between studies are complicated. The vast majority of self-efficacyrelated research has focused on mathematics and reading/ writing education, although the concept of self-efficacy has a place in health education. The instrument developed for this project used task-specific measures (ie, self-efficacy with a specific task/skill within the context of care for a real patient) as opposed to more global measures (ie, self-efficacy without a specific task/skill within the context of care real patient), and our purpose lends itself to the first research focus outlined above, in which self-efficacy is related to career development and gender differences.

The relationship between self-efficacy and gender has been studied extensively in the general area of science education. ${ }^{12-20}$ A dubious distinction is held by the former president of Harvard University, Lawrence Summers, who in 2005 suggested in a conference presentation that "there are issues of intrinsic aptitude, and particularly of the variability of aptitude" for women in science. ${ }^{21}$ In general, the studies have determined that males display higher levels of self-efficacy than do females, and in accordance with Bandura's findings, they display higher levels of achievement in science education. While these findings are often statistically significant, it is important to note that the differences are typically small in practical terms. More study is needed in the field of athletic training.

A literature search within the field of "Athletic Training," using self-efficacy and self-confidence as key words, has revealed that most studies fall into 1 of 3 distinct areas: (1) education of athletic training students, ${ }^{22-36}$ (2) rehabilitation and return-to-play considerations, ${ }^{37-45}$ and (3) confidence of athletic trainers in various practice settings with various populations..$^{46-53}$ Of the studies examining the education of athletic training students and discussing self-efficacy and/or self-confidence, several recorded gender but did not report a relationship between gender and self-efficacy and/or selfconfidence. ${ }^{23,27,29}$ Leaver-Dunn and colleagues ${ }^{23}$ found no significant relationships between gender and self-confidence using the California Critical Thinking Disposition Inventory, which included a subscale of critical-thinking self-confidence. Weidner and Popp ${ }^{27}$ studied peer-assisted learning but did not report any results related to gender and the effectiveness of peer-assisted learning or perceived benefits. Henning and colleagues $^{29}$ studied the prevalence of peer-assisted learning and the perceived benefits, such as increasing self-confidence, and reported no significant relationships between gender and self-confidence. All of these articles used interviews or 1question survey methods to assess self-confidence or selfefficacy. To date, the authors are unaware of any research that has developed a reliable efficacy-measuring instrument that analyzed gender as a contributing factor in self-efficacy ratings. Athletic trainers play a critical role in the health care of physically active patients. If educators can develop interventions to increase students' perceptions of their efficacy, they may be able to increase the students' performance on a given task. In order to gauge the effectiveness of any intervention, it is necessary to obtain a baseline measure of the students' perception of efficacy with regard to a given task. The purpose of this project was to develop and assess the reliability of the Self-Efficacy in Athletic Training Student (SEATS) instrument and to explore changes by gender over the course of 1 year. Based upon the literature and our personal anecdotal observations, we hypothesized that males would display higher levels of self-efficacy. Further, we hypothesized that males would have greater increases in selfefficacy over a 1-year period.

\section{METHODS}

\section{Participants}

A convenience sample of undergraduate athletic training students ( $\mathrm{N}=30$ students, 13 males and 17 females) ranging from 18 to 22 years in age and enrolled in a large state- 
Table 1. Athletic Training Courses Enrolled or Completed During Year of Study by Academic Cohort

\begin{tabular}{lcc}
\hline Course & Juniors $(\mathrm{n}=14)$ & Seniors $(\mathrm{n}=16)$ \\
\hline Preventative Injury Care & Completed & Completed \\
Injury Assessment-Lower Extremity & Enrolled & Completed \\
Injury Assessment-Upper Extremity & Enrolled & Completed \\
Therapeutic Modalities & Enrolled & Completed \\
\hline
\end{tabular}

sponsored Midwest university were solicited to participate. All students were enrolled in the professional phase of an athletic training program. There were 16 seniors $(7$ females and 9 males) and 14 juniors (10 females and 4 males). Table 1 depicts the course work they had completed or were enrolled in at the time of the study. No students were excluded from the project as all students provided consent. A post hoc power analysis using $G^{*}$ Power $3^{54}$ with gender and time as the 2 independent variables and self-efficacy as the dependent variable produced a statistical power level of .963 . The project was approved by the Human Subject Review Board, and informed consent was obtained.

\section{SEATS Instrument Validity and Reliability Procedure}

The SEATS instrument was derived from a previously developed set of Learning Over Time (LOT) instruments. ${ }^{55}$ The LOT instruments gave students the context of specific skills/activities with which to rate their self-efficacy. The LOT instruments were designed for completion by preceptors (formerly referred to as approved clinical instructors). To measure self-efficacy, we took the content areas (Injury Assessment, Preventative Injury Care, and Therapeutic Modalities) and components directly from the LOT instruments (see Table 2 for the components within each content area). This was done to allow for a future comparative study of instructor ratings of clinical ability and student ratings of selfefficacy. The face and content validity of the 3 content areas and associated components was established by the review of 3 education experts and 6 clinical staff members. Through several rounds of review, comments and suggestions were used to make modifications to the content areas and associated components. ${ }^{55,56}$ As the SEATS instrument was derived from the LOT instrument to be used by preceptors, the reliability of the SEATS instrument needed to be established from the perspective of the student. An internal reliability analysis using Cronbach $\alpha$ was conducted with the data from a previous project to measure and establish the reliability of the SEATS instrument.

\section{SEATS Instrument Procedures}

Students completed the instrument 3 times during the academic year $(1=$ first week of fall classes, $2=$ last week of fall semester, and 3 = last week of spring semester). For the purpose of the instrument directions, we used the term self-confidence. This approach to using the term self-confidence within the question statements is common in self-efficacy research. ${ }^{11,57,58}$ It was

Table 2. Descriptive Statistics at Each Measure and Friedman's 2-Way Analysis of Variance by Ranks; Significance Across the 3 Measures of Self-Efficacy Rating by Component for Males $(n=13)$

\begin{tabular}{llccc}
\hline & \multicolumn{3}{c}{ Content Area } \\
\cline { 2 - 3 } & $\begin{array}{c}\text { Measure } 1 \\
\text { Mean } \pm \text { SD }\end{array}$ & $\begin{array}{c}\text { Measure } 2 \\
\text { Mean } \pm \text { SD }\end{array}$ & $\begin{array}{c}\text { Measure } 3 \\
\text { Mean } \pm \text { SD }\end{array}$ & Significance \\
\hline Injury assessment & & & & .499 \\
$\quad$ History & $4.36 \pm .745$ & $4.50 \pm .650$ & $4.64 \pm .497$ & .786 \\
Observation/inspection & $4.00 \pm 1.109$ & $4.14 \pm .770$ & $4.21 \pm .579$ & .428 \\
Palpation & $3.71 \pm 1.204$ & $3.93 \pm .829$ & $4.07 \pm .730$ & .054 \\
Functional tests & $3.50 \pm 1.019$ & $3.79 \pm .893$ & $4.41 \pm .535$ & .104 \\
Special tests & $3.36 \pm .929$ & $3.50 \pm .855$ & $3.86 \pm .663$ & $.015^{*}$ \\
Neurovascular & $3.07 \pm .917$ & $3.50 \pm 1.019$ & $3.86 \pm .534$ & .148 \\
Assessment/diagnosis & $3.29 \pm 1.069$ & $3.36 \pm .929$ & $3.79 \pm .699$ & \\
Preventative injury care & & & & .657 \\
Assessment of injury & $3.79 \pm .802$ & $3.86 \pm .770$ & $4.07 \pm .616$ & .402 \\
Discuss immediate care & $3.50 \pm 1.092$ & $3.79 \pm .975$ & $4.07 \pm .829$ & $.003^{*}$ \\
Discuss return to play & $3.07 \pm 1.141$ & $3.57 \pm .756$ & $4.14 \pm .770$ & .239 \\
Demonstrate immediate care & $3.50 \pm 1.160$ & $3.93 \pm .616$ & $4.14 \pm .663$ & $.014^{*}$ \\
Demonstrate return to play & $3.29 \pm 1.204$ & $3.64 \pm .842$ & $4.29 \pm .611$ & \\
Therapeutic modalities & & & & .034 \\
Discuss indications & $3.57 \pm .938$ & $3.07 \pm .917$ & $3.93 \pm .828$ & .191 \\
Equipment set-up & $3.57 \pm 1.158$ & $3.71 \pm .995$ & $4.14 \pm .534$ & .098 \\
Demonstrate treatment & $3.43 \pm 1.225$ & $3.62 \pm 1.216$ & $4.21 \pm .699$ & .086 \\
End treatment & $3.93 \pm 1.439$ & $4.36 \pm .497$ & \\
\hline
\end{tabular}

* Statistically significant at the Bonferroni adjusted level $(.05 / 16=.003)$. 
Table 3. Descriptive Statistics at Each Measure and Friedman's 2-Way Analysis of Variance by Ranks; Significance Across the 3 Measures of Self-Efficacy Rating by Component for Females $(n=17)$

\begin{tabular}{|c|c|c|c|c|}
\hline \multirow[b]{2}{*}{ Component } & \multicolumn{3}{|c|}{ Content Area } & \multirow[b]{2}{*}{ Significance } \\
\hline & $\begin{array}{c}\text { Measure } 1 \\
\text { Mean } \pm \text { SD }\end{array}$ & $\begin{array}{c}\text { Measure } 2 \\
\text { Mean } \pm \text { SD }\end{array}$ & $\begin{array}{c}\text { Measure } 3 \\
\text { Mean } \pm \text { SD }\end{array}$ & \\
\hline \multicolumn{5}{|l|}{ Injury assessment } \\
\hline $\begin{array}{l}\text { History } \\
\text { Observation/inspection } \\
\text { Palpation } \\
\text { Functional tests } \\
\text { Special tests } \\
\text { Neurovascular } \\
\text { Assessment/diagnosis }\end{array}$ & $\begin{array}{l}4.10 \pm 1.091 \\
3.48 \pm 1.167 \\
3.19 \pm 1.167 \\
2.86 \pm 1.276 \\
2.90 \pm 1.261 \\
3.14 \pm 1.352 \\
2.52 \pm 1.167\end{array}$ & $\begin{array}{l}4.32 \pm .893 \\
3.86 \pm 1.125 \\
3.45 \pm 1.056 \\
3.46 \pm .962 \\
3.27 \pm .935 \\
3.36 \pm 1.002 \\
2.95 \pm 1.090\end{array}$ & $\begin{array}{l}4.76 \pm .538 \\
4.52 \pm .511 \\
3.95 \pm .740 \\
3.86 \pm .727 \\
3.71 \pm .717 \\
4.29 \pm .783 \\
3.62 \pm .804\end{array}$ & $\begin{array}{l}.006^{*} \\
.002^{*} \\
.026 \\
.006^{*} \\
.018^{*} \\
.001^{*} \\
.000^{*}\end{array}$ \\
\hline \multicolumn{5}{|l|}{ Preventative injury care } \\
\hline $\begin{array}{l}\text { Assessment of injury } \\
\text { Discuss immediate care } \\
\text { Discuss return to play } \\
\text { Demonstrate immediate care } \\
\text { Demonstrate return to play }\end{array}$ & $\begin{array}{l}3.10 \pm 1.091 \\
3.05 \pm 1.203 \\
2.67 \pm 1.016 \\
3.05 \pm 1.110 \\
2.71 \pm 1.189\end{array}$ & $\begin{array}{l}3.64 \pm .953 \\
3.73 \pm 1.031 \\
3.59 \pm 1.259 \\
3.82 \pm .958 \\
3.59 \pm 1.053\end{array}$ & $\begin{array}{l}4.00 \pm .632 \\
4.10 \pm .830 \\
3.81 \pm .980 \\
4.00 \pm .774 \\
3.90 \pm .768\end{array}$ & $\begin{array}{l}.001^{*} \\
.000^{*} \\
.000^{*} \\
.000^{*} \\
.000^{*}\end{array}$ \\
\hline \multicolumn{5}{|l|}{ Therapeutic modalities } \\
\hline $\begin{array}{l}\text { Discuss indications } \\
\text { Equipment set-up } \\
\text { Demonstrate treatment } \\
\text { End treatment }\end{array}$ & $\begin{array}{l}2.81 \pm 1.123 \\
4.00 \pm .774 \\
3.67 \pm 1.065 \\
3.81 \pm 1.077\end{array}$ & $\begin{array}{l}3.23 \pm 1.020 \\
3.82 \pm .732 \\
3.82 \pm .957 \\
3.86 \pm 1.082\end{array}$ & $\begin{array}{l}3.95 \pm .669 \\
4.24 \pm .768 \\
4.24 \pm .624 \\
4.52 \pm .601\end{array}$ & $\begin{array}{l}.000^{*} \\
.056 \\
.150 \\
.009^{*}\end{array}$ \\
\hline
\end{tabular}

* Statistically significant at the Bonferroni adjusted level $(.05 / 16=.003)$.

believed that students would intrinsically understand the concept of self-confidence without adding confusion by needing to define self-efficacy. For each component within each content area, students were asked to rate their confidence $(1=$ not at all confident $;=$ very confident $)$ on performing each item on a real patient in the clinical setting. The SEATS instrument was distributed in paper form and collected during lecture courses. Students were instructed during the informed consent review that their grade in the course work would not be affected by the results of this project.

\section{Data Analysis}

Data were collected and analyzed using SPSS 17.0 (SPSS Inc, Chicago, IL). Means and standard deviations were calculated for each component on each measurement occasion. A Bonferroni adjustment was made for the level of significance when analyzing each of the 3 measures, with a resulting adjusted level of significance of $.05 / 16=0.003$. The ordinal nature of the data does not meet the assumptions and power requirements for parametric analyses of variance. Consequently, a set of nonparametric analyses (Friedman's 2-way analysis of variance by ranks) were conducted. This required that males and females be examined separately. Post hoc contrasts (Friedman's 2-way analysis of variance by ranks) were conducted to determine where significant differences occurred among the 3 measures for each gender.

\section{RESULTS}

\section{Reliability Analysis of Instrument}

The reliability analysis from a previous project ${ }^{56}$ indicated that each content area and the overall SEATS instrument had high levels of interobserver reliability with a sample of convenience of 10 students. While the previous project had a different purpose, the content of the instrument was studied for consistency. A Cronbach $\alpha$ was calculated on the first measure of the current data set to estimate internal reliability (Injury Assessment, $\alpha=0.94$; Preventative Injury Care, $\alpha=$ 0.96; Therapeutic Modalities, $\alpha=0.91$; and Overall Instrument, $\alpha=0.93$ ).

\section{Nonparametric Analysis}

The dependent variables used in this study were single Likert scale items and are considered ordinal-level variables, not interval-level variables. Additionally, sample size was small, and variables were likely not fully normally distributed. Therefore, nonparametric analyses using Friedman's 2-way analysis of variance by ranks were conducted. Sixteen analyses were conducted for males, and 16 were conducted for females. The same Bonferroni-corrected $\alpha$ level was chosen $(.05 / 16=$ 0.003).

Table 2 illustrates the descriptive statistics at each measure and the analysis of variance significance level across the 3 measures for males. Males displayed significant increases in self-efficacy for only 3 components: Neurovascular $(P=.015)$ of the Injury Assessment Content Area, Discuss Return to Play $(P=.003)$, and Demonstrate Return to Play $(P=.014)$ of the Preventative Injury Care Content Area.

Table 3 illustrates the descriptive statistics at each measure and the analysis of variance significance level across the 3 measures for females. Females displayed significant increases $(P \leq .003)$ in self-efficacy for all but 4 (Palpation and Special Tests of the Injury Assessment Content Area and Equipment 
Table 4. Pairwise Comparisons of Self-Efficacy Ratings Using Friedman's 2-Way Analysis of Variance by Ranks; Significance by Component $(\mathbf{N}=\mathbf{3 0})$

\begin{tabular}{|c|c|c|c|c|c|c|}
\hline \multirow[b]{3}{*}{ Component } & \multicolumn{6}{|c|}{ Content Area } \\
\hline & \multicolumn{2}{|c|}{ Measure 1 to 2} & \multicolumn{2}{|c|}{ Measure 1 to 3} & \multicolumn{2}{|c|}{ Measure 2 to 3} \\
\hline & Male & Female & Male & Female & Male & Female \\
\hline \multicolumn{7}{|l|}{ Injury assessment } \\
\hline History & .414 & .059 & .414 & $.011^{*}$ & .317 & .020 \\
\hline Observation/inspection & .480 & .166 & .705 & $.002^{*}$ & .655 & .004 \\
\hline Palpation & .317 & .248 & .317 & $.013^{*}$ & .655 & .132 \\
\hline Functional tests & .180 & .109 & .034 & $.001^{*}$ & .317 & .405 \\
\hline Special tests & .317 & .539 & .102 & $.008^{*}$ & .083 & .096 \\
\hline Neurovascular & .059 & .998 & $.008^{*}$ & $.001^{*}$ & .414 & $.001^{*}$ \\
\hline Assessment/diagnosis & .414 & .109 & .157 & $.000^{*}$ & .096 & $.013^{*}$ \\
\hline \multicolumn{7}{|l|}{ Preventative injury care } \\
\hline Assessment of injury & .759 & .090 & .414 & $.000^{*}$ & .414 & .197 \\
\hline Discuss immediate care & .480 & $.005^{*}$ & .317 & $.000^{*}$ & .257 & .132 \\
\hline Discuss return to play & .157 & $.003^{*}$ & $.005^{*}$ & $.000^{*}$ & $.008^{*}$ & .527 \\
\hline Demonstrate immediate care & .257 & $.013^{*}$ & .157 & $.000^{*}$ & .414 & .317 \\
\hline Demonstrate return to play & .258 & $.001^{*}$ & .034 & $.000^{*}$ & $.008^{*}$ & .058 \\
\hline \multicolumn{7}{|l|}{ Therapeutic modalities } \\
\hline Discuss indications & .059 & .248 & .527 & $.000^{*}$ & .021 & $.004^{*}$ \\
\hline Equipment set-up & .763 & .317 & .059 & .248 & .157 & $.007^{*}$ \\
\hline Demonstrate treatment & .763 & .763 & .058 & .109 & .059 & .096 \\
\hline End treatment & .317 & .527 & $.011^{*}$ & $.008^{*}$ & .763 & $.013^{*}$ \\
\hline
\end{tabular}

* Statistically significant at the Bonferroni adjusted level $(.05 / 16=.003)$.

Set-Up and Demonstrate Treatment of the Therapeutic Modalities Content Area) of the 16 components.

Table 4 illustrates the pairwise post hoc comparisons of selfefficacy by component. Males had only 5 of the 16 pairwise comparisons that were statistically significant $(P \leq .003)$. None were statistically significant from measure 1 to 2 . Three (Neurovascular, Discuss Return to Play, and End Treatment) of the 16 were statistically significant from measure 1 to 3 . Two (Discuss Return to Play and Demonstrate Return to Play) of the 16 were statistically significant from measure 2 to 3 . For females there were no statistically significant $(P \leq .003)$ increases in self-efficacy from measure 1 to 2 for the Injury Assessment Content Area and the Therapeutic Modalities Content Area. There were statistically significant increases for all but 1 component (Assessment of Injury) of the Preventative Injury Care Content Area. For females, 14 of the 16 components were statistically significant from measure 1 to 3 . Six of the 16 components were statistically significant from measure 2 to 3 (Observation/Inspection, Neurovascular, and Assessment/Diagnosis of the Injury Assessment Content Area and Discuss Indications, Equipment Set-Up, and End Treatment of the Therapeutic Modalities Content Area).

\section{DISCUSSION}

Our results indicated that both time and gender were contributing factors to changes in perceptions of self-efficacy. One would expect that with time, as students learn and practice the various skill sets associated with our assessment, their perceptions of self-efficacy would change. We found significant changes in self-efficacy over the 3 measurement occasions with regard to gender. Female participants exhib- ited significant increases in self-efficacy across the 3 measure occasions for 12 of the 16 components. Conversely, male participants exhibited significant changes for only 3 components.

Martin $^{59}$ explored the relationship between gender and teachers' perceptions of self-confidence in their students' engagement and motivation. Male teachers' ratings of selfconfidence were markedly higher than those of females for perceptions of their students' persistence and planning. We found that males had higher initial ratings of self-efficacy for 11 of the $16(68 \%)$ components at measure 1 but for only 9 of the $16(56 \%)$ components at measure 3. Females displayed greater average overall increased changes in self-efficacy across the 3 measures $(.90 \pm .36)$ when compared with males $(.61 \pm .32)$.

Kruger and Dunning ${ }^{60}$ found that people tend to hold overly favorable views of their abilities in many domains. They found that people scoring in the bottom quartile on various tests grossly overestimated their performance and abilities. As they stated, "Not only do these people reach erroneous conclusions and make unfortunate choices, but their incompetence robs them of the metacognitive ability to realize it." In other words, they are unconsciously ignorant about their lack of ability. This is a similar concept to that of The Reflective Practitioner, as discussed by Donald Schön. ${ }^{61}$ Schön $^{61}$ suggested that people move from being unconsciously ignorant about a given task or skill through 2 intermediary stages to finally become unconsciously competent. This may explain why we found that males had greater initial levels of self-efficacy for the majority of components at measure $1(68 \%)$ but not at measure $3(56 \%)$. Perhaps, as time progressed between 
measures, the males began to realize their true abilities and adjusted their ratings of efficacy accordingly. Stewart et $a^{62}$ explained that confidence must be tempered with knowledge of limitations, weaknesses, and competence.

Gardner-Medwin and Gahan ${ }^{63}$ studied confidence-based assessments in which students rated their confidence in giving an answer to a question. They found no differences in ratings of confidence based upon gender. While this finding contradicts our results for the initial measure, it is supported by our results for the final measure, in which the difference between genders is negligible. Their findings are related to those of Kruger and Dunning ${ }^{60}$ in that appropriate feedback is important: "The aim is to encourage reflection, selfawareness, and the expression of appropriate levels of confidence."

Students require appropriate corrective feedback in order to properly assess their competence level and thus properly calibrate ratings of self-efficacy. With proper assessments of competence and self-efficacy students can self-determine areas of strength and weakness. Dependence upon student selfassessments alone is perilous at best. Research has shown that students' self-assessment of their abilities often differs from the assessment afforded by peer assessments ${ }^{64}$ or actual skill demonstration. ${ }^{65,66}$

Development of interventions to increase students' selfefficacy may improve the students' performance. The development of a reliable method of measuring self-efficacy will allow educators to determine a baseline of their students' perceptions of self-efficacy and, thus, the effectiveness of the interventions. The development and reliability analysis of the SEATS instrument was sound and based upon established scientific principles. ${ }^{67}$ The content validity argument is based upon a review of experts in both the didactic and clinical settings of athletic training education. The estimates of reliability for the instrument were high and are thus acceptable. ${ }^{67}$

\section{Limitations and Suggestions for Future Research}

Several outside factors that cannot be controlled could be contributors to the observed changes in self-efficacy in this study. The course sequence and where a student stands in his matriculation through the sequence could have a direct effect upon the student's self-efficacy within a given content area. Future studies should analyze changes with regard to the class level/cohort. This study was limited to a single year with 30 students at 1 institution. It would be interesting to follow a larger sample size and several cohorts of students across the entire curriculum. The quality of clinical experiences cannot be controlled. Variability among a large staff of preceptors and a large number of clinical sites means that some students will get more practice with the specific tasks and skills than others and thus may have higher levels of self-efficacy in particular areas of the SEATS instrument. Expanding this study to multiple institutions could begin to address the consistency of preceptors and clinical rotations by expanding the number of participants and thus applying the law of averages. The athletic training program in which this study was conducted was concurrently collecting data in a study on peer-assisted learning. The literature supports the contention that peer-assisted learning may increase self-confidence. ${ }^{27}$ As part of this peer-assisted learning study students were randomly assigned to 1 of 3 test groups, and thus their levels of self-efficacy may have been affected by the group they were in when the data were collected. Future studies should address the issue of interventions designed to increase self-efficacy and their impact on the education of the students.

\section{CONCLUSIONS}

As Bandura's self-efficacy model stated, increased levels of self-efficacy can lead to increased performance. However, Morgan and Cleave-Hogg ${ }^{66}$ found no correlation between level of efficacy and performance on a standardized simulation test or clinical grades. Educators need to be aware of their students' self-efficacy on given skills, develop interventions to increase the ratings of self-efficacy, and perhaps improve performance on those skills. Our findings can be summarized as follows:

- Males had higher initial levels of self-efficacy than did females.

- Females had higher average increases in self-efficacy across time.

This study found that males have higher levels of self-efficacy but that this difference was attenuated as females' overall levels of self-efficacy increased more over time than did those of males, ultimately to similar levels. A reliable method for measuring levels of self-efficacy has been developed and tested for athletic training education on a defined set of skills. It is the hope of the authors that readers will adapt our instrument to their particular needs and use it as part of an overall assessment system.

\section{REFERENCES}

1. Bandura A. Self-efficacy: toward a unifying theory of behavioral change. Psych Rev. 1977;84(2):191-215.

2. Bandura A. Social Foundations of Thought and Action: A Social Cognitive Theory. Englewood Cliffs, NJ: Prentice Hall; 1986.

3. Charlton R. Education about death and dying at Otago University Medical School. N Z Med J. 1993;106(966):447-449.

4. Schwiebert LP, Davis A. Impact of a required third-year family medicine clerkship on student confidence in cognitive and procedural skills. Teach Learn Med. 1995;7:37-42.

5. Pajares F. Self-efficacy beliefs in academic settings. Rev Educ Res. 1996;66(4):543-578.

6. Lent R, Brown S, Larkin K. Self-efficacy in the prediction of academic performance and perceived career options. J Counsel Psych. 1986;33(3):265-269.

7. Lent R, Hackett G. Career self-efficacy: empirical status and future directions. J Vocation Behav. 1987;30(3):347-382.

8. Schunk D. Self-efficacy perspective on achievement behavior. Educ Psych. 1984;19(1):48-58.

9. Schunk D. Goal setting and self-efficacy during self-regulated learning. Educ Psych. 1990;25(1):71-86.

10. Schunk D. Self-efficacy and academic motivation. Educ Psych. 1991;26(3):207-231.

11. Bandura A. Perceived self-efficacy in cognitive development and functioning. Educ Psych. 1993;28(2):117-148. 
12. Baker D. Sex differences in classroom interactions in secondary science. J Class Interact. 1986;22(2):6-12.

13. Boylan CR, Hill DM, Wallace AR, Wheeler AE. Beyond stereotypes. Sci Educ. 1992;76(5):465-476.

14. Fennema E, Peterson P. Autonomous learning behavior: a possible explanation of gender-related differences in mathematics. Gender Influences Classroom Interact. 1985:17-35.

15. Hyde JS, Fennema E, Lamon SJ. Gender differences in mathematics performance: a meta-analysis. Psych Bull. 1990; 107(2):139-155.

16. Hyde JS, Linn MC. Gender differences in verbal ability: a metaanalysis. Psych Bull. 1988;104(1):53-69.

17. Johnson S. Gender differences in science: parallels in interest, experience and performance. Int J Science Educ. 1987;9(4):467481.

18. Kahle JB, Parker LH, Rennie LJ, Riley D. Gender differences in science education: building a model. Educ Psych. 1993;28(4):379404.

19. Kelly A. The construction of masculine science. Brit J Soc Educ. 1985;6(2):133-154.

20. Parker LH, Offer JA. School science achievement: conditions for equality. Int J Sci Educ. 1987;9(3):263-269.

21. Summers L. Faculty diversity: research agenda. Paper presented at: Diversifying the Sciences \& Engineering Workforce: Women, Underrepresented Minorities, and Their Science \& Education Careers; January 14-15, 2005; Cambridge, MA.

22. Meyer LP. Athletic training clinical instructors as situational leaders. J Athl Train. 2002;37(suppl 4):S261-S265.

23. Leaver-Dunn D, Harrelson GL, Martin M, Wyatt T. Criticalthinking predisposition among undergraduate athletic training students. J Athl Train. 2002;37(suppl 4):S147-S151.

24. Mensch J, Ennis C. Pedagogic strategies perceived to enhance student learning in athletic training education. J Athl Train. 2002;37(suppl 4):S199-S207.

25. Weidner TG, Henning JM. Development of standards and criteria for the selection, training, and evaluation of athletic training approved clinical instructors. J Athl Train. 2004;39(4): 335-343.

26. Weidner TG, Laurent T. Selection and evaluation guidelines for clinical education settings in athletic training. J Athl Train. 2001; 36(1):62-67.

27. Weidner TG, Popp JK. Peer-assisted learning and orthopaedic evaluation psychomotor skills. J Athl Train. 2007;42(1):113-119.

28. Walker SE. Journal writing as a teaching technique to promote reflection. J Athl Train. 2006;41(2):216-221.

29. Henning JM, Weidner TG, Jones J. Peer-assisted learning in the athletic training clinical setting. J Athl Train. 2006;41(1):102-108.

30. Erickson MA, Martin M. Contributors to initial success on the National Athletic Trainers' Association Board of Certification examination as perceived by candidate sponsors: a delphi study. J Athl Train. 2000;35(2):134-138.

31. Dodge TM, Mitchell MF, Mensch JM. Student retention in athletic training education programs. J Athl Train. 2009;44(2): 197-207.

32. Klossner $\mathrm{J}$. The role of legitimation in the professional socialization of second-year undergraduate athletic training students. J Athl Train. 2008;43(4):379-385.
33. Peer KS, McClendon RC. Sociocultural learning theory in practice: implications for athletic training educators. $J$ Athl Train. 2002;37(suppl 4):S136-S140.

34. Pitney WA, Ehlers GG. A grounded theory study of the mentoring process involved with undergraduate athletic training students. J Athl Train. 2004;39(4):344-351.

35. Lauber CA, Toth PE, Leary PA, Martin RD, Killian CB. Program directors' and clinical instructors' perceptions of important clinical-instructor behavior categories in the delivery of athletic training clinical instruction. J Athl Train. 2003;38(4): 336-341.

36. Barnum MG. Questioning skills demonstrated by approved clinical instructors during clinical field experiences. J Athl Train. 2008;43(3):284-292.

37. Byerly PN, Worrell T, Gahimer J, Domholdt E. Rehabilitation compliance in an athletic training environment. $J$ Athl Train. 1994;29(4):352-355.

38. Fisher AC, Scriber KC, Matheny ML, Alderman MH, Bitting LA. Enhancing athletic injury rehabilitation adherence. J Athl Train. 1993;28(4):312-318.

39. Glazer DD. Development and preliminary validation of the Injury-Psychological Readiness to Return to Sport (I-PRRS) Scale. J Athl Train. 2009;44(2):185-189.

40. Johnson MB, Thiese SM. A review of overtraining syndromerecognizing the signs and symptoms. J Athl Train. 1992;27(4): 352-354.

41. Hamson-Utley JJ, Martin S, Walters J. Athletic trainers' and physical therapists' perceptions of the effectiveness of psychological skills within sport injury rehabilitation programs. $J$ Athl Train. 2008;43(3):258-264.

42. Granito VJ Jr, Hogan JB, Varnum LK. The performance enhancement group program: integrating sport psychology and rehabilitation. J Athl Train. 1995;30(4):328-331.

43. Wagman D, Khelifa M. Psychological issues in sport injury rehabilitation: current knowledge and practice. J Athl Train. 1996;31(3):257-261.

44. Harris LL. Integrating and analyzing psychosocial and stage theories to challenge the development of the injured collegiate athlete. J Athl Train. 2003;38(1):75-82.

45. Conatser P, Naugle K, Tillman M, Stopka C. Athletic trainers' beliefs toward working with Special Olympics athletes. $J$ Athl Train. 2009;44(3):279-285.

46. Drummond JL, Hostetter K, Laguna PL, Gillentine A, Del Rossi G. Self-reported comfort of collegiate athletes with injury and condition care by same-sex and opposite-sex athletic trainers. $J$ Athl Train. 2007;42(1):106-112.

47. Drummond JL, Velasquez BJ, Cross RS, Jones ML. Selfreported comfort in athletic training of gender-specific and nongender-specific injuries and issues. J Athl Train. 2005;40(3):211217.

48. Vaughan JL, King KA, Cottrell RR. Collegiate athletic trainers' confidence in helping female athletes with eating disorders. $J$ Athl Train. 2004;39(1):71-76.

49. Zientek CE, Dewald LL. Cancer detection: the educational role of the athletic trainer. J Athl Train. 1998;33:45-49.

50. Reed S, Giacobbi PR Jr. The stress and coping responses of certified graduate athletic training students. J Athl Train. 2004; 39(2):193-200. 
51. Stiller-Ostrowski JL, Ostrowski JA. Recently certified athletic trainers' undergraduate educational preparation in psychosocial intervention and referral. J Athl Train. 2009;44(1):67-75.

52. Geisler PR. Multiculturalism and athletic training education: implications for educational and professional progress. $J$ Athl Train. 2003;38(2):141-151.

53. Newsham KR. Athletic training students with disabilities: a survey of entry-level education programs. J Athl Train. 2006; 41(4):409-414.

54. Faul F, Erdfelder E, Lang AG, Buchner A. G* Power 3: a flexible statistical power analysis program for the social, behavioral, and biomedical sciences. Behav Res Methods. 2007; 39(2):175-191.

55. Carr WD, Ploeger RL, Drummond J. AT education learning over time: a literature review and case study. Athl Ther Today. 2007;12(5):20-25.

56. Carr WD, Volberding J. Development of athletic training learning over time instruments. Athl Ther Today. 2010;15(1): $11-17$.

57. Pajares F, Miller M. Role of self-efficacy and self-concept beliefs in mathematical problem solving: a path analysis. J Educ Psych. 1994;86(2):193-203.

58. Shell D, Murphy C, Bruning R. Self-efficacy and outcome expectancy mechanisms in reading and writing achievement. $J$ Educ Psych. 1989;81(1):91-100.

59. Martin AJ. The relationship between teachers' perceptions of student motivation and engagement and teachers' enjoyment of and confidence in teaching. Asia-Pacific J Teach Educ. 2006; 34(1):73-93.

60. Kruger J, Dunning D. Unskilled and unaware of it: how difficulties in recognizing one's own incompetence lead to inflated self-assessments. J Person Soc Psych. 1999;77(6):11211134.

61. Schön D. The Reflective Practitioner: How Professionals Think in Action. London, United Kingdom: Temple Smith; 1983.

62. Stewart J, O'Halloran C, Barton JR, Singleton SJ, Harrigan P, Spencer J. Clarifying the concepts of confidence and competence to produce appropriate self-evaluation measurement scales. Med Educ. 2000;34(11):903-909.

63. Gardner-Medwin AR, Gahan M. Formative and summative confidence-based assessment. Paper presented at: International Computer-Aided Assessment Conference; July 2003; Loughborough, United Kingdom.

64. Arnold L, Willoughby T, Calkins EV. Self-evaluation in undergraduate medical education: a longitudinal perspective. $J$ Med Educ. 1985;60(1):21-28.

65. Panek P, Sterns H. Self-evaluation, actual performance and preference across the life-span. Exp Aging Res. 1985;11(4):221223.

66. Morgan PJ, Cleave-Hogg D. Comparison between medical students' experience, confidence and competence. Med Educ. 2002;36(6):534-539.

67. Frey B. Statistics Hacks. Sebastopol, CA: O'Reilly Media Inc; 2006. 